
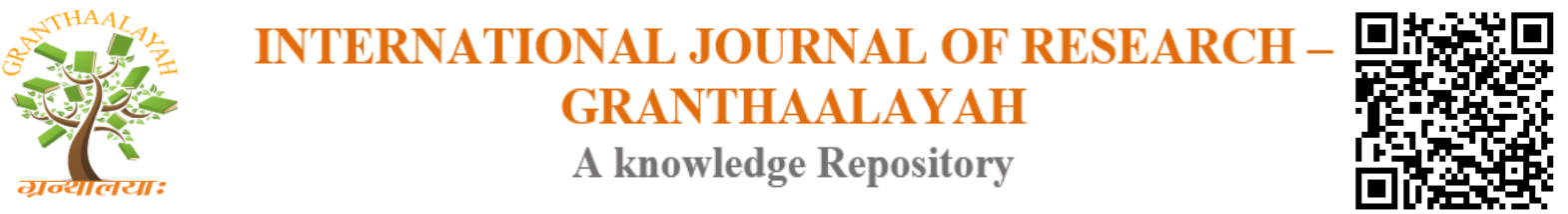

Social

\title{
ADJUSTMENT PROBLEM AND ITS IMPACT ON ACHIEVEMENT IN MATHEMATICS AMONG SECONDARY SCHOOL STUDENTS
}

\author{
P. Surya ${ }^{1}$, Mr.S.Mahendran ${ }^{2}$ \\ ${ }^{1}$ M. Ed Scholar, RVS College of Education Sulur, India \\ ${ }^{2}$ M.A., M.Ed. Assistant Professor in Pedagogy of History, RVS College of Education Sulur, \\ India
}

\begin{abstract}
Adjustment problem has impacted on student activities, behavior, health and education in general. The study aimed to examine the adjustment problem and its impact on achievement in mathematics among secondary school students. The investigator adopted survey method to study the impact of adjustment problem and its impact on achievement in mathematics among secondary school students. For this study a sample of 300 secondary school students from four Govt and Private schools which are situated in Dindigul district in Tamil Nadu were selected by the investigator using simple random sampling technique. The findings reveal that there is significant mean score difference in adjustment problems and its impact on academic achievement in mathematics among secondary school students.
\end{abstract}

Keywords: Mathematics; Students; Adjustment Problem; Schools.

Cite This Article: P. Surya, and Mr.S.Mahendran. (2017). “ADJUSTMENT PROBLEM AND ITS IMPACT ON ACHIEVEMENT IN MATHEMATICS AMONG SECONDARY SCHOOL STUDENTS." International Journal of Research - Granthaalayah, 5(7), 603-607. https://doi.org/10.29121/granthaalayah.v5.i7.2017.2169.

\section{Introduction}

Adjustment to schooling is influenced by a variety of personal and family Characteristics, and societal trend. It is the interaction of the child's personal characteristics and their experiences that ultimately determines how a child adjusts to school (Margetts, 2002).

Adjustment is to achieve mental or behavioral balance between one's own needs and the demands of others as a result of which the individual is put to a more satisfactory state. Academic achievement is the knowledge or skill developed in the school subjects usually designed by the test scores on marks assigned by the teachers. A brilliant child who is doing mathematics only slightly better than average work would be making and unsatisfactory adjustment. At the same time a child very limited potential in mathematics might be though as 
making satisfactory adjustment of his achievements even though blow average is commensurate with his ability.

A number of research and studies have been done on adjustment problem. According to Mahmondi (2010) found that gender had no differential influence over adjustment scores in home, health, emotional and social area. Lama (2010) reported that there is a great tendency for female students to experience adjustment problems more than males. This finding implies that male students are better adjusted in overall adjustment on the campus as compared to female students. Whereas Roy, Ekka and Ara (2011) observed that female students were better adjusted than male students. Basu (2012) aimed to investigate the adjustment abilities of secondary school students and found that there exist highly significant differences between the adjustment of secondary school students when compared on the basis of gender, types of family structure and medium of instruction in school.

\section{Research Design}

The investigator adopted survey method to study adjustment problem and its impact on achievement in mathematics among secondary school students. For this study a sample of 300 secondary school students from four Govt and Private schools which are situated in and around Dindigul district in Tamil Nadu were selected by the investigator using simple random sampling technique.

\section{HYPOTHESES 1:}

There will be a significant mean score difference in adjustment problems and its impact on academic achievement in mathematics among secondary school students

Table 1: Mean score difference in adjustment problems and its impact on academic achievement in mathematics among secondary school students.

\begin{tabular}{|l|l|l|l|l|l|l|l|l|}
\hline \multicolumn{9}{|c|}{ Adjustment problem } \\
\hline \multicolumn{3}{|c|}{ Low } & \multicolumn{3}{c|}{ Moderate } & \multicolumn{3}{c|}{ High } \\
\hline Q1 & F & \% & Q2 & F & \% & Q3 & F & \% \\
\hline 47 & 38 & 15.66 & 143 & 41 & 47 & 110 & 44 & 36.67 \\
\hline
\end{tabular}

Table 1 exhibits the result of adjustment problem among school students at secondary level. According to the table totally $15.66 \%$ of the students at secondary level belong to low level of adjustment problem and achievement. $47 \%$ of the students at secondary level belong to moderate level of adjustment problem and achievement, and $36.67 \%$ of the students at secondary level belong to high level of adjustment problem and achievement. sohypothses 1 is accepted Thus it is inferred that there is a difference in the level of adjustment problem and achievement among students at secondary level.

\section{HYPOTHESES 2:}

There will be a significant mean score difference in Adjustment Problems based on Gender among the selected secondary school students. 
Table 2: Mean score difference in Adjustment Problems based on Gender among the selected secondary school students.

\begin{tabular}{|l|l|l|l|l|l|l|l|l|}
\hline Variable & & N & Mean & S.D & Df & $\begin{array}{c}\text { t- } \\
\text { value }\end{array}$ & p-value & Result \\
\hline \multirow{3}{*}{ Gender } & Male & 155 & 41.72 & 1.64 & & & & \multirow{2}{*}{298} \\
\cline { 2 - 9 } & Female & 145 & 41.63 & 1.56 & 0.541 & 1.96 & NS \\
\cline { 2 - 9 } & Total & 300 & & & & & & \\
\hline
\end{tabular}

Table 2 shows that Mean score difference in Adjustment Problems based on Gender among the selected secondary school students. The calculated t-value (0.541)is not statistically significant at 0.05 level and hence, the hypothesis 2 is Rejected. It can be concluded that there is a no significant Mean score difference in Adjustment Problems based on Gender among the selected secondary school students.

Histogram

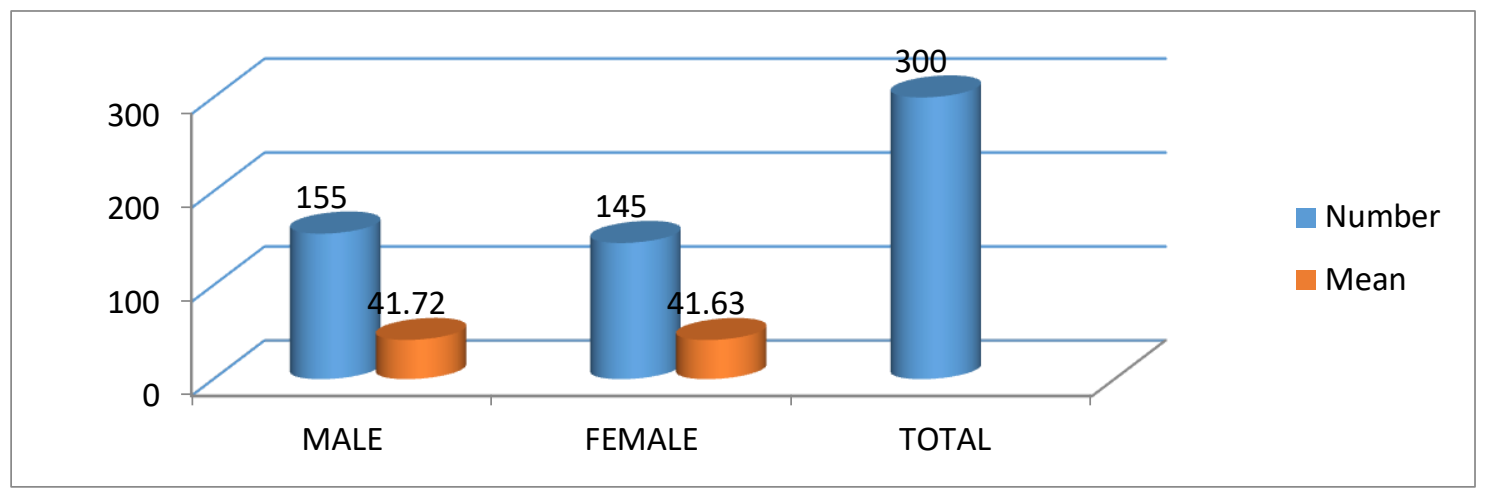

\section{HYPOTHESES 3:}

There will be a significant mean score difference in Adjustment Problems between the groups based on Locality among the secondary school students.

Table 3: Mean score difference in Adjustment Problems between the groups based on Locality among the secondary school students.

\begin{tabular}{|l|l|l|l|l|l|l|l|l|}
\hline \multirow{2}{*}{ Variable } & & N & Mean & S.D & df & t-value & p-value & \multirow{2}{*}{ Result } \\
\hline \multirow{2}{*}{ Locality } & Rural & 183 & 42.66 & 1.47 & & & & \\
\cline { 2 - 9 } & Urban & 117 & 41.42 & 1.81 & 298 & 6.21 & 1.96 & S \\
\cline { 2 - 8 } & Total & 300 & & & & & & \\
\hline
\end{tabular}

Table 3 shows that Mean score difference in Adjustment Problems based on Locality among the selected secondary school students. The calculated t-value (6.21) is statistically significant at 0.05 level and hence, the hypothesis 3 is accepted. It can be concluded that there is a significant 
Mean score difference in Adjustment Problems based on Locality among the selected secondary school students.

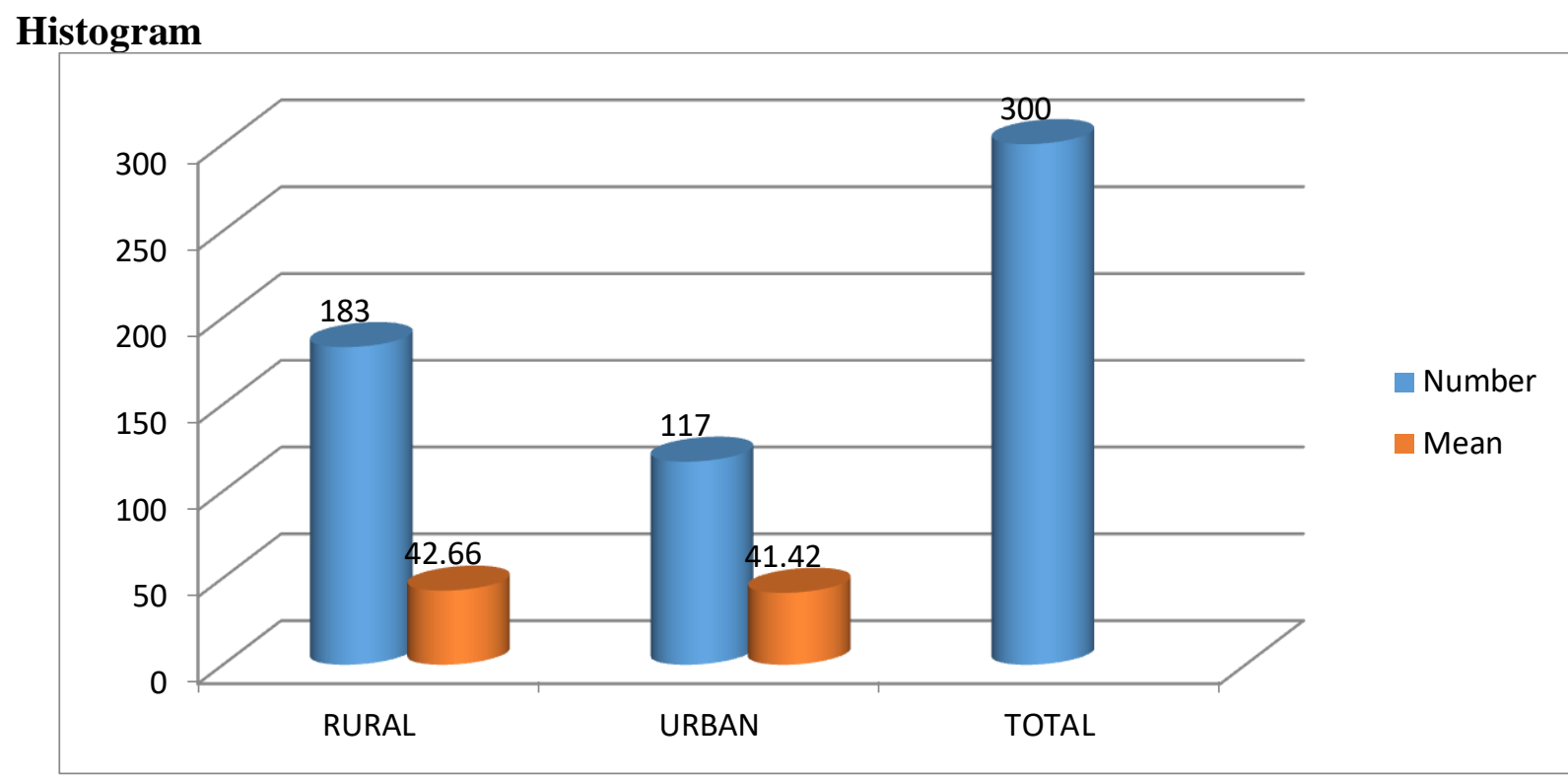

\section{Conclusion}

The findings reveal that $15.66 \%$ of secondary school students belong to low level impact on achievement. $47 \%$ of secondary school students belong to moderate level impact on achievement. $36.67 \%$ of secondary school students belong to high level impact on achievement. Also it is found that there is a significant impact of adjustment problems on academic achievement in mathematics among secondary school students.

\section{References}

[1] Abraham M. A study of certain psycho-social correlates of mental health status of university entrants of Kerala. Kerala (Psychology). 1985.

[2] Adhiambo WM, Odwar AJ, Mildred AA. The relationship among school adjustment, gender and academic achievement amongst secondary school students in Kisumu district Kenya. Journal of emerging Trends in Educational research and policy studies. 2011;2(6):493-7.

[3] Agarwal\&Sapna (2000). CINI ASHA: The purpose of the study to determine Building bridges for urban children, in Ramchandran, V. (ed.), Getting children back to school, case studies in Primary Education, Sage Publications, NewDelhi.

[4] Agarwal, K. (2003). The purpose of the study to determine A comparative study of adolescent's level of adjustment in relation to the academic success and failure. Indian Journal of Psychometric and Education, 134 (2), 172- 176.

[5] Adhiambo W.M., Odwar, A. J. \& Mildred, A. A.(2011). The purpose of the study to determine The relationship among school adjustment, gender and academic achievement amongst secondary school students in Kisumu district Kenya. Journal of Emerging Trends in Educational Research and Policy Studies, 26, 493-497.

[6] Akhtar, Z. (2012). Adjustment pattern among private and government school students. Journal of Psychological Researches, 56(2), 97-104. 
[7] Basu, S. (2012). Adjustment of secondary school students. Scholarly Research Journal for Interdisciplinary Studies, 1(3), 430- 438.

[8] Bharadwaj SK, Helode RD. School adjustment as a function of neuroticism and gender of the adolescents. Indian Psychological Review. 2006; 66(1):25.

[9] Chauhan, V. (2013). A study on adjustment of higher secondary school students of Durgdistrict,IOSR Journal of Research \& Method in Education, 1(1) 50-52

[10] Chen, F.S., Lin, Y.M. \&Tu, C.A. (2006). A Study of the Emotional Intelligence and Life Adjustment of Senior High School Students, World Transactions on Engineering and Technology Education Vol.5, No.3, 473-476.

\footnotetext{
*Corresponding author.

E-mail address: psuryapriya@ gmail.com
} 